\title{
Synthesis and Application of Manganese Oxide Catalysts in Oxidation and Hydrogenation Processes
}

\author{
Vitali Shalva Bakhtadze \\ R. I. Agladze Institute of Inorganic Chemistry and Electrochemistry, Tbilisi, Georgia
}

\section{Email address:}

vbakhtkat@yahoo.com

\section{To cite this article:}

Vitali Shalva Bakhtadze. Synthesis and Application of Manganese Oxide Catalysts in Oxidation and Hydrogenation Processes. Modern Chemistry. Vol. 9, No. 3, 2021, pp. 52-60. doi: 10.11648/j.mc.20210903.12

Received: August 20, 2021; Accepted: September 7, 2021; Published: September 26, 2021

\begin{abstract}
The analysis is made of the results of performed investigations: elaboration and study of physical-chemical properties of the catalysts on the basis of manganese oxides and on their use in various fields of chemical industry. Physical-chemical and technological foundations of the formation of oxide-manganese catalyst-absorbent of new-type are validated. It has been shown that for processes of purification of combustible gases from $\mathrm{H}_{2} \mathrm{~S}$ and organic sulphur compounds he most favorable thermodynamic and kinetical conditions are created at manganese catalyst the composition of which near to $\mathrm{Mn}_{3} \mathrm{O}_{4}$. This type of the catalyst, together with $\mathrm{MnO}_{2}$ and, partially with $\mathrm{Mn}_{2} \mathrm{O}_{3}$, hold a firm own place in the catalytic processes. The direction, associated with the use of modified alumooxide carrier for elaboration of oxide-manganese and metallic catalysts (Pt, Pd) became as the new and prospective in the technology of carriers and catalysts, used in the processes of oxidation and hydrogenation. Technological modes, realized in given method, provide to activate solid-phase reaction of the formation of calcium aluminates at lower temperatures, as well as to stabilize surface-structural characteristics and to enhance thermal stability and mechanical strength of modified carrier. In the technology of the catalysts of aluminium oxide, by the use, of the carrier, preliminary modified by calcium oxide, the $\mathrm{Mn}-\mathrm{Pd}$ catalyst was elaborated available for oxidation of $\mathrm{CO}$ and hydrocarbons of spent gases of the motor transport. The addition of palladium to the oxide-manganese catalyst leads to the formation of new centers on the surface which are active in the reaction of $\mathrm{CO}$ oxidation. The processes of the formation of manganese catalysts in reaction medium were studied. The method for preparing of the Mn-Pd catalyst includes processing the samples with an ammonia water solution. Treatment of the catalyst with ammonia water causes the formation of a palladium ammonia complex, which decomposes witha formation of palladium black. It can be concluded that the treatment with ammonia water leads to the completion of the formation of the active surface of the catalyst and to the temperature decrease of complete oxidation of CO. The experience of industrial operation of catalysts on the basis of modified alumocalcium carriers has shown that by duration of efficient operation of reburning of discharged gases of the engines of internal combustion they may compete with well-known industrial marks of the catalysts.
\end{abstract}

Keywords: Purification of Gases, Modified Alumocalcium Carriers, Oxide-manganese Catalyst-adsorbent, Thermocatalitic Decomposition of $\mathrm{H}_{2} \mathrm{~S}$, Alumosilicate-cordierite Blocks, Formation Mn·Pd-catalist for CO Oxidation

\section{Introduction}

Improvement of heterogenous catalysts and elaboration of new highly active and selective catalytic systems is one of the major problems of chemical science and industry.

At purification of technological gases from oxygen, hydrogen, ozone, hydrocarbons, nitrogen oxides, carbon monoxide the catalysts on the basis of the noble metals (platinum, palladium) are characterized by maximal activity. Deficit and high cost, as well as their insufficient strength and thermal stability required the performance of the researches in the search of new available and efficient catalysts for the processes of gas purification as well as for the realization of other chemical-technological processes. From among of the large group of oxide catalysts, manganese oxides are the most highly active in oxidation processes. 
Manganese stable oxides: $\mathrm{MnO}_{2}, \mathrm{Mn}_{2} \mathrm{O}_{3}, \mathrm{Mn}_{3} \mathrm{O}_{4}$ and $\mathrm{MnO}$ are differ from one another by their crystallochemical as well as by adsorption and other physical-chemical properties. Electron structure of mentioned oxides significantly varies (depending on the oxygen content) which, probably, has a pronounced effect on their catalytic activity. Selection of oxide-manganese composition, as an active component, for elaboration of the catalysts for gas purification is also determined by the following factors:

1) catalytic activity of manganese oxides in comparison with the other oxides in the reaction of oxidation of carbon monooxide and hydrogen, oxygen hydrogenation, nitrogen oxides and in the other processes;

2) high stability of manganese sulfide in gaseous area of the mixture $\mathrm{H}_{2} \mathrm{~S}-\mathrm{H}_{2}$ which determines its high activity in the process of gas purification from hydrogen sulfide and organic sulphur compounds.

3) availability of raw material (manganese natural compounds or the waste material of manganese production), which is used at catalyst synthesis.

Mentioned factors determined the scientific and practical importance of the researches on the study of catalytic and physical-chemical properties of manganese oxides in the reactions of oxidation and hydrogenation.

The works on heterogenous catalysis were mainly directed to the elaboration and study of physical-chemical properties and on the use of the catalysts manganese oxides in the processes of desulfurization of combustible gases, at purification of technological gases of chemical production and exhaust gases of the vehicles [1-3].

\section{Oxide - Manganese Catalysts - Absorbents}

\subsection{Desulphurization of Combustible Gases with Manganese Contacts}

Manganese method for desulfurization of combustible gases and liquid fuel is the important achievement in the field of industrial catalysis [1, 2]. High sulfur absorbance of manganese contacts in reducing medium may be explained by the ability of manganese oxides for stopping of reducing processes at the stage of sulfide formation. Because of this fact they are different from iron oxides in which the process is proceeded up to the formation of metallic iron. Cubic structures of Mn (II) oxide and of sulfide - MnS close by parameters, are favourable for total sulfurization of the oxides of Mn (II) and Mn (III) (Table 1).

Table 1. Cubic structures of $\mathrm{MnO}$ and $\mathrm{MnS}$.

\begin{tabular}{ll}
\hline Structures unit & Parameters $\boldsymbol{\alpha}, \mathbf{A}$ \\
\hline $\mathrm{MnO}$ & 4.436 \\
$\mathrm{MnS}$ & 5.611 \\
\hline
\end{tabular}

Table 2. Chemical composition of the concentrates of manganese oxide ores (wt.\%).

\begin{tabular}{lllllll}
\hline $\mathbf{N}$ & $\mathbf{M n O}$ & $\mathbf{M n O}$ & $\mathbf{S i O}_{2}$ & $\mathbf{A l}_{2} \mathbf{O}_{3}$ & $\mathbf{F e}_{2} \mathbf{O}_{3}$ \\
\hline $\mathrm{I}^{*}$ & $20.0 \div 92.0$ & - & $2.0 \div 45.0$ & $2.0 \div 10.0$ & $1.5 \div 5.0$ & $2.0 \div 20.0$ \\
$\mathrm{II}^{* *}$ & $1.0 \div 3.0$ & $30.0 \div 90.0$ & $2.0 \div 25.0$ & $2.0 \div 13.0$ & $1.5 \div 5.0$ & $2.5 \div 25.0$ \\
\hline
\end{tabular}

*Initial sample;

${ }^{* *}$ Reduced by nitrogen-hydrogen mixture at $650 \div 700^{\circ} \mathrm{C}, 2 \mathrm{~h}$

New sulphur absorbers were studied and proposed for practical use (on the basis of low-grade manganese ores), characterized by high activity and sulphur capacity. The mechanism and kinetics of the processes of purification of combustible gases from sulphur compounds: $\mathrm{CS}_{2}$ and $\mathrm{H}_{2} \mathrm{~S}$ were studied [4]. Inspite of the efficiency, a wide practical use of such catalysts in modern high-technology processes is limited by their insufficient operating characteristics: small specific surface, low mechanical and thermal stability, single use of a mass. Further researches were dedicated to the elaboration of new competitive catalysts with improved thermal-mechanical and surface-structural characteristics. The technology for preparation of pilled catalysts from the powders, containing manganese oxides, is proposed. The concentrates of manganese natural ores of Chiatura deposit (Georgia) were used for preparation of the tablets. Chemical composition of initial concentrates before and after reducing by nitrogen-hydrogen mixture at $650 \div 700^{\circ} \mathrm{C}$ for 2 his presented in Table 2.

Pilot lot of oxide-manganese catalyst - adsorbent was manufactured by elaborated technology at rotor tabletting machine of two-way filling (Table 3). The prepared tabletes are characterized by a totality of the pores of various radius. Along with it, the main part involves the pores of low and medium radius.

Table 3. Some physical-chemical characteristics of pilot lot of pelleted oxide-manganese catalyst-adsorbent (pellet size d=9 $\mathrm{mm}$, height $h=5 \mathrm{~mm}$ ).

\begin{tabular}{|c|c|c|c|c|c|c|}
\hline \multicolumn{3}{|c|}{ Pore radius $-\mathbf{r}$} & \multirow{2}{*}{ Pore volume, $\mathrm{cm}^{3} / \mathrm{g}$} & \multirow{2}{*}{ Specific surface, $\mathrm{m}^{2} / \mathrm{g}$} & \multirow{2}{*}{ Mechanical strength, $\mathrm{kg} / \mathrm{cm}^{2}$} & \multirow{2}{*}{ Bulk density, $\mathbf{g} / \mathrm{cm}^{3}$} \\
\hline to-100 Å & $100 \div 1000 \AA$ & $>1000 \AA$ & & & & \\
\hline $\begin{array}{l}80 \AA \\
100 \AA\end{array}$ & $\begin{array}{l}250 \AA \\
750 \AA\end{array}$ & $\begin{array}{l}3500 \AA \\
5000 \AA \\
100000 \AA\end{array}$ & 0.35 & $40 \div 50$ & $70 \div 80$ & $1.4 \div 1.5$ \\
\hline
\end{tabular}

Performed investigation has shown that tableted oxide-manganese catalyst-adsorbent absorbs efficiently a sulfur at cleaning of natural gas from $\mathrm{H}_{2} \mathrm{~S}$ in temperature range from $350^{\circ} \mathrm{C}$ to $400^{\circ} \mathrm{C}$. Critical sulfur content comprises $15-17$ 
wt. s\%. Pellets of oxide-manganese catalyst-adsorbent, prepared by elaborated method, by its activity, absorbance and operating regime is in good competition with some types of zinc adsorbent and by mechanical strength and thermal stability has the better indexes.

\subsection{Formation of Phase Composition of Oxide-manganese Catalyst-absorbent}

The major part of the works is dedicated to the study of the processes of formation of manganese catalysts in reaction medium. Certain peculiarities of the process of formation of manganese catalysts were determined in the reactions of oxidation of $\mathrm{CO}$ and $\mathrm{H}_{2}$. The electric conductivity of natural pyrolusite and the products of its reduction, as well as of alumo-manganese catalysts in various reagent medium was studies. The data were obtained on variation of the potential of the surface of $\mathrm{CO}$ and $\mathrm{H}_{2}$ in relation to the volume. It was shown that the variation of the potential between granule surface and center is mainly determined by variation of the ratio between concentration and oxygen bond energy and depth oxygen. The conclusion was made that the reaction of $\mathrm{CO}$-oxidation in peroxide ore proceeds by mixed oxidation-reduction and adsorption mechanism [5]. The certain correlation between the value of the potential of surface and activity of manganese catalyst was established in the reaction of CO-oxidation depending on the process temperature [6]. The assumption was made that optimal catalyst for the processes in reduction medium process is close to $\mathrm{Mn}_{3} \mathrm{O}_{4}$. It was established that the optimal composition of manganese catalyst varies in the range: $\mathrm{MnO}-\mathrm{MnO}_{1,15}$ at obligatory presence of $\mathrm{MnO}$-phase. This type of the catalyst, together with $\mathrm{MnO}_{2}$ and, partially with $\mathrm{Mn}_{2} \mathrm{O}_{3}$, hold a steady own place in the catalytic processes $[2,7]$.

\subsection{Thermocatalytic Decomposition of $\mathrm{H}_{2} \mathrm{~S}$ into $\mathrm{H}_{2}$ and Sulfur}

The activity of pelleted manganese oxide and cobalt-manganese catalysts supported on a calcium alumina carrier A - $1 \mathrm{M}$ mark was studied in the course of thermocatalytic decomposition of $\mathrm{H}_{2} \mathrm{~S}$ into hydrogen and sulfur $[8,9]$. On a cobalt-manganese catalyst, a stable degree of $\mathrm{H}_{2} \mathrm{~S}$ conversion of the order of $50-70 \%$ is achieved in the temperature range of $800-1000^{\circ} \mathrm{C}$. The X-ray diffraction pattern of the sulfided cobalt-manganese catalyst (Table 4.) identified the phases of the $\alpha-\mathrm{MnS}$ and $\mathrm{y}-\mathrm{MnS}$ modification of manganese sulfide, partial cobalt sulfide $\mathrm{Co}_{9} \mathrm{~S}_{8}$ and modifications of calcium aluminates $3 \mathrm{CaO} \cdot 5 \mathrm{Al}_{2} \mathrm{O}_{3}(3 \mathrm{C} \cdot 5 \mathrm{~A})$ and $\mathrm{CaO} \cdot 2 \mathrm{Al}_{2} \mathrm{O}_{3}\left(\mathrm{CA}_{2}\right)$. Apparently stable sulfides $\alpha-\mathrm{MnS}$ and $\mathrm{Co}_{9} \mathrm{~S}_{8}$ determine the activity of the cobalt-manganese catalyst in the process of decomposition of $\mathrm{H}_{2} \mathrm{~S}$ into hydrogen and sulfur.

Table 4. The results of Roentgen Phase Analysis of carriers A - 1M mark and sulphurized Co:Mn catalyst.

\begin{tabular}{|c|c|c|c|c|c|c|}
\hline Sample & Phase Ca & & & & & \\
\hline $\mathrm{A}-1 \mathrm{M} / 1400^{\circ} \mathrm{C}$ & $\alpha-\mathrm{Al}_{2} \mathrm{O}_{3}$ & - & - & - & $3 \mathrm{C} \cdot 5 \mathrm{~A}$ & $\mathrm{C} \cdot 2 \mathrm{~A}$ \\
\hline $\mathrm{A}-1 \mathrm{M} / 1400^{\circ} \mathrm{C}+4-5$ mass. $\% \mathrm{Co}: \mathrm{Mn}=4: 1$ & $\alpha-\mathrm{Al}_{2} \mathrm{O}_{3}$ & $\alpha-\mathrm{MnS}$ & $\gamma-\mathrm{MnS}$ & $\mathrm{Co}_{9} \mathrm{~S}_{8}$ & $3 \mathrm{C} \cdot 5 \mathrm{~A}$ & $\mathrm{C} \cdot 2 \mathrm{~A}$ \\
\hline
\end{tabular}

\section{Modified Alumocalcium Carriers and Catalysts for Gas Purification}

\subsection{Interaction of Modification ( $\left.\gamma-, \chi_{-}, \alpha e-, \alpha-\right)-\mathrm{Al}_{2} \mathrm{O}_{3}$ with Calcium Oxide}

The large cycle of the researches is dedicated to solving the ecological problems. For this reason the works were performed on elaboration and study of activity and physical-chemical properties of manganese catalyst for oxidation of $\mathrm{CO}$ and hydrocarbons, contained in the end gases of chemical production and in the exhaust gases of the vehicles [3].

In catalyst technology the low-temperature modifications of aluminum oxide are widely used, particularly $\gamma-\mathrm{Al}_{2} \mathrm{O}_{3}$. But in pure state, without additional technological treatment, they are not entirely suited to the preparation of high-temperature catalysts. Physical-chemical properties of oxide-aluminum carriers may be improved by introducing of small amounts of modifiers. They form the thermally stable compounds with aluminum oxide, which characterized by higher thermal mechanical and catalyc properties than initial aluminum oxide. Amongof the possible modifiers (oxides of $\mathrm{Mg}$. $\mathrm{Ba}, \mathrm{Ca}$ ) improving the physical-chemical characteristics of alumina carriers, calcium oxide is of the greatest interest. Calcium and aluminum cations differ in ionic radia and give a chemical compound of the $\mathrm{xCaO}$ type $\cdot \mathrm{yAl}_{2} \mathrm{O}_{3}$ at comparatively low temperatures. In work [10] it was shown that at modifying of aluminum oxide by cations of calcium on the surface the coordinating-unsaturated ions $\mathrm{Ca}^{++}$are formed which generate new electron-acceptor centers. After thermal treatment in the system $\mathrm{CaO} \cdot \mathrm{Al}_{2} \mathrm{O}_{3}$ the complex phase transformations occur causing the formation of calcium aluminates: $\mathrm{CaO} \cdot \mathrm{Al}_{2} \mathrm{O}_{3}(\mathrm{CA})$, $\mathrm{CaO} \cdot 2 \mathrm{Al}_{2} \mathrm{O}_{3}\left(\mathrm{CA}_{2}\right)$ and high-temperature phase $æ-\mathrm{Al}_{2} \mathrm{O}_{3}$.

In practice, calcium oxide can be introduced into the alumina carrier in the form of oxide, carbonates, or soluble calcium salts at various technological stages of preparing of the modified carrier. Thermodynamic analysis showed high reactivity of calcium oxide obtained by dissociation of calcium nitrate and the probability of aluminate formation in the temperature range $600-1000^{\circ} \mathrm{C}$. In accordance with the theory of physical-chemical mechanics of disperse bodies [11] the characteristic peculiarity of given area $(600-900)^{\circ} \mathrm{C}$ involves the intense interaction reaction between highly disperse phase of calcium oxide (which acts as an amorphous phase) and crystalline phase of aluminum oxide (presents a rigid skeleton). Such combination of the phases is the most favorable for creation of mechanically strong structure.

Certain peculiarities of interaction between single modifications: $\gamma-, \chi$-, $æ-$ and $\alpha-\mathrm{Al}_{2} \mathrm{O}_{3}$ and calcium oxide at their various ratio and temperature were studied in. Concentration limits of the formation of calcium aluminates 
$\mathrm{CA}_{2}$ and CA were determined. It was shown that the phases of mono- and dialuminates of calcium may be formed by regulation of the content of calcium oxide in the carrier as well as depending on the modification of the latter (Table 5) [12]. They differ from one another by the structure of crystalline lattice and by main physical-chemical characteristics.

Table 5. Phase composition of the samples of $\mathrm{Al}_{2} \mathrm{O}_{3}$ of various modifications in the mixture with $\mathrm{CaO}$ after thermal treatment at $900^{\circ} \mathrm{C}$ over 16 hours.

\begin{tabular}{|c|c|c|c|}
\hline \multirow{2}{*}{ Sample composition } & \multicolumn{2}{|c|}{ Content of crystallized phases } & \multirow{2}{*}{$\begin{array}{l}\text { Phase ration } \\
\left(\mathrm{CA} / \mathrm{CA}_{2}\right)\end{array}$} \\
\hline & $\mathbf{C A}$ & $\mathbf{C A}_{2}$ & \\
\hline$\gamma-, \chi-\mathrm{Al}_{2} \mathrm{O}_{3}+5$ mass $\%$ of $\mathrm{Ca}$ & - & main & - \\
\hline$\gamma-, \chi-\mathrm{Al}_{2} \mathrm{O}_{3}+15$ mass $\%$ of $\mathrm{Ca}$ & main & main & $1: 1$ \\
\hline$æ-\mathrm{Al}_{2} \mathrm{O}_{3}+5$ mass $\%$ of $\mathrm{Ca}$ & to 5 mass $\%$ & main & 1: 9 \\
\hline$æ-\mathrm{Al}_{2} \mathrm{O}_{3}+15$ mass $\%$ of $\mathrm{Ca}$ & main & main & 1: 1 \\
\hline$\alpha-\mathrm{Al}_{2} \mathrm{O}_{3}+5$ mass $\%$ of $\mathrm{Ca}$ & main & - & - \\
\hline$\alpha-\mathrm{Al}_{2} \mathrm{O}_{3}+15$ mass $\%$ of $\mathrm{Ca}$ & main & - & - \\
\hline
\end{tabular}

\subsection{Phase Transformations in the $\mathrm{CaO}-(\gamma-, \chi-)-\mathrm{Al}_{2} \mathrm{O}_{3}$ System}

Initial carrier of mark: $\mathrm{ShN}-2$ is $\gamma$ - and $\chi-\mathrm{Al}_{2} \mathrm{O}_{3}$. At thermal treatment the phase transformations take place by formation of $\alpha$-, $æ$ - and $\theta$ phases of aluminum oxide which, by visual estimation of the intensity, are in the following ratios: $\alpha-\mathrm{Al}_{2} \mathrm{O}_{3}$ $\sim 40-50 \%, æ-\mathrm{Al}_{2} \mathrm{O}_{3} \sim 40-50 \%$, and $\theta-\mathrm{Al}_{2} \mathrm{O}_{3}$, which, probably doesn't exceed $5-10 \%$. Mass content of $\gamma-\mathrm{AlO}(\mathrm{OH})$, by visual estimation, doesn't exceed 1-3 mass\%. Roentgenograms of the samples $\mathrm{ShN}-2 \mathrm{M}$ of initial and burnt at $1000^{\circ} \mathrm{C}$ over 50 hours are totally identical in regard to phase composition of the components. Phase structure of the sample $\mathrm{ShN}-2 \mathrm{M}$ conforms to two compounds: $\mathrm{CA}_{2}-40 \%$ and $æ-\mathrm{Al}_{2} \mathrm{O}_{3} \sim 60 \%$. Other impurity phases were not found (Table 6).

At introducing of $\mathrm{CaO}$ in $\mathrm{ShN}-2$ up to 1.0 mass\% the rate of phase transformations of $\gamma-, \chi-\mathrm{Al}_{2} \mathrm{O}_{3}$ became slower and more sharply than the temperature of thermal treatment is higher. Roentgenograms of the sample series, containing nearly $1 \%$ of $\mathrm{CaO}$ and burnt at $880-900$ and $1000^{\circ} \mathrm{C}$, testify about deceleration of the crystallization processes of $æ-\mathrm{Al}_{2} \mathrm{O}_{3}$, as well as of other phases of aluminum oxide. Increase of $\mathrm{CaO}$ crystallization of $æ-\mathrm{Al}_{2} \mathrm{O}_{3}$ in the sample $\mathrm{ShN}-2+4 \div 5$ mass $\%$ of $\mathrm{CaO}$, burnt at $1000^{\circ} \mathrm{C}$, the phase $-\mathfrak{x}-\mathrm{Al}_{2} \mathrm{O}_{3}$ almost isn't observed. At this temperature the new phase $-\mathrm{CA}_{2}$ is formed instead of the process of phase transformations of aluminum oxide. Increase of $\mathrm{CaO}$ concentration to $7-8$ mass $\%$ doesn't change the character of phase transformations which proceed in the samples containing $4-5$ mass $\%$ of $\mathrm{CaO}$. All roentgenograms of the samples $\mathrm{ShN}-2+(7-8)$ mass $\%$ of $\mathrm{CaO}$ are similar, in appearance, to corresponding roentgenograms of series $\mathrm{ShN}-2+(4-5)$ mass $\%$ of $\mathrm{CaO}$.

Table 6. Phase composition of the samples of the carriers $S h N-2$ and $S h N-2 M$ after thermal treatment at $1000^{\circ} \mathrm{C}$ over 50 hours.

\begin{tabular}{|c|c|}
\hline Sample & Phase composition, mass \% \\
\hline$\gamma-, \chi-\mathrm{Al}_{2} \mathrm{O}_{3}(\operatorname{markShN}-2)$ & $\begin{array}{l}\alpha-\mathrm{Al}_{2} \mathrm{O}_{3} \sim 40-50 \% ; \mathfrak{x}-\mathrm{Al}_{2} \mathrm{O}_{3} \sim 40-50 \% \\
\theta-\mathrm{Al}_{2} \mathrm{O}_{3}-\text { no more than } 5-10 \% \\
\gamma-\mathrm{AlO}(\mathrm{OH}) \text { no more than } 1-3 \%\end{array}$ \\
\hline $\mathrm{CA}_{2}, \circledast-\mathrm{Al}_{2} \mathrm{O}_{3}$ (markShN-2M) & $\begin{array}{l}\mathrm{CA}_{2} \sim 40 \% ; \mathfrak{x}-\mathrm{Al}_{2} \mathrm{O}_{3} \sim 60 \% \\
\text { presence of other phases wasn't found }\end{array}$ \\
\hline
\end{tabular}

In the Table 7 the main physical-chemical characteristics of the carriers ShN-2 and ShN-2M are given. As is seen the carrier ShN-2M is characterized by considerably higher strength and has the wider combination of working pores (100-2000 $\AA$ ).

Table 7. Characteristics of granulated carriers on the basis of $\mathrm{Al}_{2} \mathrm{O}_{3}$.

\begin{tabular}{llllllc}
\hline $\begin{array}{l}\text { Carrier } \\
\text { mark }\end{array}$ & Phase composition & $\begin{array}{l}\text { Granule size, } \\
\mathbf{m m}\end{array}$ & $\begin{array}{l}\text { Bulk density, } \\
\mathbf{g} / \mathbf{c m}^{\mathbf{3}}\end{array}$ & $\begin{array}{l}\text { Total porosity, } \\
\mathbf{c m}^{\mathbf{3}} / \mathbf{g}\end{array}$ & $\begin{array}{l}\text { Pore size, } \mathbf{\AA} \\
\begin{array}{l}\text { Area of specific } \\
\mathbf{s u r f a c e}, \mathbf{~ m} / \mathbf{g}\end{array}\end{array}$ & $\begin{array}{l}\text { Strength on } \\
\mathbf{c r u s h i n g}, \mathbf{k g} / \mathbf{c m}^{2}\end{array}$ \\
\hline $\mathrm{ShN}-2$ & $\gamma, \chi-\mathrm{Al}_{2} \mathrm{O}_{3}$ & $4-5$ & 0.85 & $0.33-0.40$ & $100-1000$ & $100-120$ \\
$\mathrm{ShN}-2 \mathrm{M}$ & $æ-\mathrm{Al}_{2} \mathrm{O}_{3} \mathrm{CaO}-2 \mathrm{Al}_{2} \mathrm{O}_{3}$ & $4-5$ & $0.85-0.9$ & $0.35-0.40$ & $100-2000$ & $80-90$ \\
\hline
\end{tabular}

Performed research has shown that the considerable improvement of physical-chemical and thermal-mechanical properties of carriers from $\gamma, \chi-\mathrm{Al}_{2} \mathrm{O}_{3}$ may be realized by their modifying by calcium oxide. Alumo-calcium carrier with optimal content of calcium oxide (4-5 mass\%) is characterized by significantly higher strength and has more wide combination of working pores $(100-2000 \AA)$ than non-modified and some well-known carrier, used for catalyst preparation. New technology for modification of the carriers from aluminum oxide by calcium oxide has been proposed. Technological modes, realized in given method, allows to activate solid-phase reaction of the formation of calcium aluminates at lower temperatures, as well as to stabilize surface-structural characteristics and to enhance thermal stability and mechanical strength of modified carrier $[13,14]$.

\subsection{Activity of Mn-Pd, Pd, and Pt Catalysts on a Calcium Alumina Support in the Oxidation Reaction of $\mathrm{CO}$ and Butane}

On the basis of modified carrier ShN-2M the manganese-palladium MPK-1, PLK-1 and PLK-2 and 
palladium catalysts of NPK series for oxidation of CO and hydrocarbons were elaborated (Tables 8,9 ). Catalysts were tested at coordination Center of Comecon on industrial catalysts, Catalysts Institute, Novosibirsc.

Palladium catalyst (to 0.2 mass\% of $\mathrm{Pd}$ ) exceeds other samplesby activity, especially, in the reaction of butane deep oxidation. These data are in good accordance with the results of laboratory and operative testing of pilot samples of NPK-2 in the systems of purification of discharged gases of gasoline as well as diesel engines. Catalysts NPK-2 retains high activity at mileage duration of "LIAZ" bus (more than resource norm- $80 \cdot 10^{3} \mathrm{~km}$ ) in the reactions of oxidation of CO and propane. By these indices, catalyst NPK-2 exceeds well-known Pd- and Pt-catalysts (Table 10) [15] Testing was performed at the stand in the branch of NІСТІД (Moscow) by procedure, described in.

Laboratory, bench and operative testings of pilot samples of catalysts PLK-1 in the systems of neutralization of discharge gases of diesel autoloader have shown that by activity they are not worse and by durability are considerably better that the catalysts of well-known firms. Toyota and TCM [16].

Palladium catalyst NPK- $0.3 \%$ Pd was introduced in the process of one-stage hydrogenation of phenol to cyclohexanone at the Rustavi p/o "Azot" (1984-1985). This method was first released on a pilot scale in the production of caprolactam [13].

The experience of industrial operation of catalysts on the basis of modified alumocalcium-carriers has shown that by duration of efficient operation of reburning of discharged gases of the engines of internal combustion they may compete with well-known industrial marks of the catalysts.

Table 8. Physical-chemical characteristics of catalysts on carrier ShN-2M and temperatures of attaining of specific transformation degree of CO (\%).

\begin{tabular}{|c|c|c|c|c|c|c|c|c|}
\hline \multirow{2}{*}{$\begin{array}{l}\text { Catalyst } \\
\text { mark }\end{array}$} & \multirow{2}{*}{$\begin{array}{l}\text { Bulk density, } \\
\mathrm{g} / \mathrm{cm}^{3}\end{array}$} & \multirow{2}{*}{$\begin{array}{l}\text { Specific } \\
\text { surface, } \mathrm{m}^{2} / \mathrm{g}\end{array}$} & \multirow{2}{*}{$\begin{array}{l}\text { Pore total } \\
\text { volume, } \mathrm{cm}^{3} / \mathrm{g}\end{array}$} & \multirow{2}{*}{$\begin{array}{l}\text { Strength, } \\
\mathrm{kg} / \mathrm{cm}^{2}\end{array}$} & \multicolumn{4}{|c|}{ Temperature of attaining of $\mathrm{CO}$ transformation degree, ${ }^{\circ} \mathrm{C}$} \\
\hline & & & & & $25 \%$ & $\mathbf{5 0 \%}$ & $75 \%$ & $85 \%$ \\
\hline MPK-1 & 0.78 & 98 & 0.27 & 114 & 151 & 156 & 159 & 161 \\
\hline NPK-2 & 0.86 & 93 & 0.32 & 120 & 112 & 113 & 114 & 115 \\
\hline PLK-1 & 0.85 & 116 & 0.35 & 125 & 151 & 153 & 154 & 156 \\
\hline PLK-2 & 0.86 & 118 & 0.33 & 116 & 136 & 138 & 143 & 152 \\
\hline
\end{tabular}

Note: Reagent mixture: $1,001 \%$ of $\mathrm{CO}+$ air; $\mathrm{g}_{\text {cat }}-1 \mathrm{~g}$, grain diameter $-4 \mathrm{~mm}$; volume rate $10000 \mathrm{~h}^{-1}$.

Table 9. Catalyst activity on carrier $\mathrm{ShN}-2 \mathrm{M}$ in the butane oxidation reaction (reagent mixture: 0.5 vol. $\%$ of $\mathrm{C}_{4} \mathrm{H}_{10}+$ air; $\mathrm{g}_{\text {cat }}-5 \mathrm{~g}$ ).

\begin{tabular}{|c|c|c|c|c|}
\hline \multirow{2}{*}{ Catalyst mark } & \multirow{2}{*}{ Grain fraction, $\mathbf{m m}$} & \multicolumn{3}{|c|}{ Reaction rate $\times 10^{2} \mathrm{~cm}^{3} \mathrm{C}_{4} \mathrm{H}_{10} /$ s.g. catalyst } \\
\hline & & $300^{\circ} \mathrm{C}$ & $350^{\circ} \mathrm{C}$ & $400^{\circ} \mathrm{C}$ \\
\hline \multirow{2}{*}{ MPK-1 $(0.05 \%$ Pd $)$} & 4 & 0.068 & 0.028 & 1.26 \\
\hline & $1-2$ & 0.083 & 0.48 & 2.34 \\
\hline \multirow{2}{*}{ PLK-1 $(0.1 \% \mathrm{Pt})$} & 4 & 0.052 & 0.11 & 0.19 \\
\hline & $1-2$ & 0.048 & 0.14 & 0.24 \\
\hline \multirow{2}{*}{ PLK-2 (0.2\% Pt) } & 4 & 0.08 & 0.123 & 0.23 \\
\hline & $1-2$ & 0.079 & 0.25 & 0.37 \\
\hline \multirow{2}{*}{ NPK-2 $(0.2 \%$ Pd $)$} & 4 & 0.042 & 0.27 & 1.59 \\
\hline & $1-2$ & 0.047 & 0.31 & 5.88 \\
\hline
\end{tabular}

Table 10. Activity of initial and spent catalyst NPK-2 in the systems of purification of spent gases of bus "LIAZ" in the reaction of oxidation of CO and propane $\left(\mathrm{W}=30 \cdot 10^{3} \cdot \mathrm{h}^{-1}, V_{\text {cat }}=5 \mathrm{ml}\right.$, grain size $=5 \mathrm{~mm}$, reagent mixture: $0.36 \mathrm{vol} \% \mathrm{C}_{3} \mathrm{H}_{8}+$ air $)$.

\begin{tabular}{|c|c|c|c|c|c|c|c|c|c|}
\hline \multirow[t]{2}{*}{ Sample } & \multirow[t]{2}{*}{ Mileage, km } & \multicolumn{4}{|c|}{$\begin{array}{l}\text { Temperatures of attaining of } \\
\text { CO-transformation degree, }{ }^{\circ} \mathrm{C}\end{array}$} & \multirow{2}{*}{$\begin{array}{l}\text { Specificsurface, } \\
\mathrm{m}^{2} / \mathrm{g}\end{array}$} & \multirow{2}{*}{$\begin{array}{l}\text { Bulk mass, } \\
\mathrm{kg} / \mathrm{dm}^{2}\end{array}$} & \multirow{2}{*}{$\begin{array}{l}\text { Strength, } \\
\mathrm{kg} / \mathrm{cm}^{2}\end{array}$} & \multirow{2}{*}{$\begin{array}{l}\mathrm{T}^{\circ} \mathrm{C} \alpha-\mathrm{C}_{3} \mathrm{H}_{8} \\
-\mathbf{5 0} \%\end{array}$} \\
\hline & & $25 \%$ & $50 \%$ & $75 \%$ & $90 \%$ & & & & \\
\hline \multirow{3}{*}{$\begin{array}{l}\text { NPK-2 pilot batch } \\
\text { from } 28.12 .1979\end{array}$} & - & 120 & 114 & 147 & 215 & 122.0 & 0.86 & 110.0 & 367 \\
\hline & 30000 & 170 & 175 & 182 & 380 & - & - & - & 340 \\
\hline & 148863 & 152 & 153 & 154 & 167 & 93.0 & 0.867 & - & 312 \\
\hline
\end{tabular}

\section{Manganese-Palladium Catalysts for CO Oxidation}

\subsection{Dispersion and Phase Composition of Oxide-manganese Catalysts on Alumina and Alumina-calcium Carriers}

Manganese-palladium catalyst MPK-1, containing minimum amount of palladium (up to 0.05 mass $\%$ ) is prospective for the use in the systems of gas purification.
Catalyst MРК-1, in comparison with well-known examples of the given group of the catalysts, is characterized by enhanced activity and retains the stability of surface-structural properties over long-term testing [17]. In accordance with regulations for preparation of experimental-industrial parties the carrier ShN-2M, manganese containing component (4-5 mass $\%)$ and palladium ( 0.05 mass $\%)$ are incorporated in the composition of MPK-1. X-ray phase analysis of mentioned catalysts shows the presence of $\beta-\mathrm{Mn}_{2} \mathrm{O}_{3}$ phase with crystallite size of $300 \AA$, traces of $\alpha-\mathrm{Mn}_{2} \mathrm{O}_{3}$ phase or $\mathrm{Mn}_{3} \mathrm{O}_{4}$ phase and carrier phase. 
In the Table 11 the characteristics of studied samples of the catalysts are given: chemical composition, temperature of additional burning of prepared samples, specific surface, phase composition, crystallite size [17]. Carrier ShN-2 on aluminum oxideis, obtained by dehydration of gibbsite and pseudobemite at $600^{\circ} \mathrm{C}$. Carrier $\mathrm{ShN}-2$ involves the phases: $\chi-\mathrm{Al}_{2} \mathrm{O}_{3}$ and $\gamma-\mathrm{Al}_{2} \mathrm{O}_{3}$. On diffraction spectrum of modified carrier $\mathrm{ShN}-2 \mathrm{M}$ the phases $æ-\mathrm{Al}_{2} \mathrm{O}_{3}$ and calcium dialuminate $\mathrm{CaO} \cdot 2 \mathrm{Al}_{2} \mathrm{O}_{3}$ are identified together with the phases of the carrier $\mathrm{ShN}-2$.

Diffraction pictures of catalyst: 1,0 mass $\% \mathrm{Mn} / \mathrm{ShN}-2$ and carrier ShN-2 are practically identical. Parameter of the cell of the phase of carrier ShN-2 $(\alpha=7.880 \AA)$ is more than parameter of the cell of carrier phase in catalyst ( $\alpha=7.869 \AA)$, which is, probably, determined by formation of solid solution at catalyst preparation: $\mathrm{Mn}^{4+}$-ions are incorporated in the structure of alumooxide phase of carrier (radius $\mathrm{r}\left(\mathrm{Mn}^{4+}\right)=0.52 \AA$ is less than radius $\mathrm{r}\left(\mathrm{Al}^{3+)}=0.57 \AA\right.$. Additional burning of the sample over 25 hours at $900^{\circ} \mathrm{C}$ doesn't lead to the appearance of crystallic modifications of manganese containing compounds.

In the catalyst, containing $4-5$ mass $\%$ of $\mathrm{Mn}$, the phase
$\mathrm{MnO}_{2}$ is identified together with carrier phases. $\mathrm{MnO}_{2}$ content $\approx 7.6 \%$ which in terms of $\mathrm{Mn}$ comprises $4.8 \%$. Crystallite size of $\mathrm{MnO}_{2}$ phase comprises $350 \AA$. Parameter of the cell of carrier phase: $\gamma-\mathrm{Al}_{2} \mathrm{O}_{3}$ is reduced in comparison with the parameter of carrier cell by $0.011 \AA$. Catalyst, involving 10 mass\% of $\mathrm{Mn}$, contains $\mathrm{MnO}_{2}$ phase in the quantity of $14.2 \%$, which in terms of Mn comprises $9 \%$. Crystallite size for $\mathrm{MnO}_{2}$ phase comprises $610 \AA$, as in previous samples the solid solution of $\mathrm{Mn}^{4+}$-ions in carrier structure in fixed.

For catalyst: 1.0 mass $\% \mathrm{Mn} / \mathrm{ShN}-2 \mathrm{M}$, burnt at $400-450^{\circ} \mathrm{C}$ over 25 hours as well as for the samples $\mathrm{Mn} / \mathrm{ShN}-2 \mathrm{M}$, the formation of solid solution is typical, catalyst with 4-5 mass \% $\mathrm{Mn}$ on $\mathrm{ShN}-2 \mathrm{M}$ contains carrier phase $\gamma-\mathrm{Al}_{2} \mathrm{O}_{3}$ with reduced parameter, phase $\beta-\mathrm{Mn}_{2} \mathrm{O}_{3}$ with crystallite size of $500 \AA$ to the extent of 2,4 mass $\%$ and phase $\beta-\mathrm{MnO}_{2}$ with particle size $\approx 300$ Åto the extent of 2,0 mass $\%$. The latter is identified only after sample burning at $400-450^{\circ} \mathrm{C}$ over 25 hours. Catalyst containing 10 mass \% of $\mathrm{Mn}$ involves solid solution $\left(\alpha=7.869 \AA\right.$ ) of spinel structure: $2.4 \% \beta-\mathrm{Mn}_{2} \mathrm{O}_{3}$ and $5.4 \mathrm{mass} \%$ of $\beta-\mathrm{MnO}_{2}$ with crystallite size $\approx 600 \AA$.

Table 11. Physical-chemical characteristics of Mn-Pd catalysts on the carriers $S h N-2$ and $S h N-2 M$ depending on the content of active component.

\begin{tabular}{|c|c|c|c|c|}
\hline $\begin{array}{l}\text { Chemical composition } \\
\text { mass \% }\end{array}$ & $\begin{array}{l}\text { Temperature additional } \\
\text { burning, }{ }^{\circ} \mathrm{C}\end{array}$ & Specific surface $\mathrm{m}^{2} / \mathrm{g}$ & Phase composition & Crystallite size, $\AA$ \\
\hline ShN-2 & - & $90-100$ & $\chi-\gamma-\mathrm{Al}_{2} \mathrm{O}_{3}$ & - \\
\hline $1,0 \mathrm{Mn} / \mathrm{ShN}-2$ & - & 105 & $\begin{array}{l}\text { active component } \mathrm{MnO}_{\mathrm{x}} \\
\text { roentgenoamorphous }++ \text { carrier }\end{array}$ & - \\
\hline 4-5 Mn/ShN-2 & - & 98 & $\beta-\mathrm{MnO}_{2}+$ carrier & $350\left(\beta-\mathrm{MnO}_{2}\right)$ \\
\hline 9-10 Mn/ShN-2 & - & $90-100$ & $\beta-\mathrm{MnO}_{2}+$ carrier & $610\left(\beta-\mathrm{MnO}_{2}\right)$ \\
\hline $\mathrm{ShN}-2 \mathrm{M}$ & - & $80-90$ & $æ-\mathrm{Al}_{2} \mathrm{O}_{3}, \mathrm{CaO}-2 \mathrm{Al}_{2} \mathrm{O}_{3}$ & - \\
\hline $1.0 \mathrm{Mn} / \mathrm{ShN}-2 \mathrm{M}$ & $400-450$ ( 25 hours) & 95 & $\begin{array}{l}\text { active component } \mathrm{MnO}_{\mathrm{x}} \\
\text { roentgenoamorphous+carrier }\end{array}$ & - \\
\hline 4-5 Mn/ShN-2M & $400-450$ (25 hours) & 90 & $\begin{array}{l}\beta-\mathrm{Mn}_{2} \mathrm{O}_{3} \\
\beta-\mathrm{MnO} 2+\text { carrier }\end{array}$ & $\begin{array}{l}500\left(\beta-\mathrm{Mn}_{2} \mathrm{O}_{3}\right) 300 \\
\left(\beta-\mathrm{MnO}_{2}\right)\end{array}$ \\
\hline 9-10 Mn/ShN-2M & - & $85-90$ & $\begin{array}{l}\beta-\mathrm{Mn}_{2} \mathrm{O}_{3} \\
\beta-\mathrm{MnO}_{2}+\text { carrier }\end{array}$ & $\begin{array}{l}600\left(\beta-\mathrm{Mn}_{2} \mathrm{O}_{3}\right) 600 \\
\left(\beta-\mathrm{MnO}_{2}\right)\end{array}$ \\
\hline $\begin{array}{l}\text { MPK-1 } \\
(4-5 \mathrm{Mn} ; 0.05 \mathrm{Pd} / \mathrm{ShN}-2 \mathrm{M}\end{array}$ & - & $88-90$ & $\begin{array}{l}\mathrm{CaO}-2 \mathrm{Al}_{2} \mathrm{O}_{3} \text { traces } \\
\beta-\mathrm{Mn}_{2} \mathrm{O}_{3} \text {-base } \\
\alpha-\mathrm{Mn}_{2} \mathrm{O}_{3}-\text { imparities } \\
\mathrm{Mn}_{3} \mathrm{O}_{4} \text { - imparities }\end{array}$ & $300\left(\beta-\mathrm{Mn}_{2} \mathrm{O}_{3}\right)$ \\
\hline
\end{tabular}

Comparison of texture characteristics and activity of the $\mathrm{Mn}-\mathrm{Pd}$ catalysts on calcium aluminate carrier $\left(\mathrm{CaO} \cdot 2 \mathrm{Al}_{2} \mathrm{O}_{3}\right.$, $\mathrm{CA}_{2}$ ) of $\mathrm{ShN}-2 \mathrm{M}$ mark in the reaction of $\mathrm{CO}$ oxidation has shown that, the sample with $4.0 \div 5.0$ wt. $\%$ of $\mathrm{Mn}+0.05$ wt. $\%$ of $\mathrm{Pd}$ content was proved to be the most active. On the carrier, apart from the phase of $\beta-\mathrm{MnO}_{2}$, the formation of the phase $\beta-\mathrm{Mn}_{2} \mathrm{O}_{3}$ is observed in nearly equal proportion. The addition of palladium to the oxide-manganese catalyst leads to the formation of new centers on the surface which are active in the reaction of $\mathrm{CO}$ oxidation.

\subsection{Surface-texture Morphology of Palladium-promoted and Sulfated MPK-1 Catalysts}

In Figure 1 the images of surface relief of the samples of $\mathrm{Mn}-\mathrm{Pd}$ (MPK) catalysts with various Pd-content are presented. For Mn-Pd catalysts with the difference, that, besides of Pd-particles, on the surface the particles of manganese oxide of the shape of semispherical petals may be observed. Increase of palladium concentrate from 0.023 to 0.06 mass $\%$ causes almost total overlapping of the surface by palladium particles. In this case it may be concluded that palladium really covers the surface occupied by manganese oxide and doesn't penetrate in pore depth, choked by the particles of manganese oxide [18, 19]. The data, obtained by electron microscopy [20], testify that introduction of Pd and $\mathrm{Mn}$ in hydrothermally treated $\gamma-\mathrm{Al}_{2} \mathrm{O}_{3}$ causes the interaction of active components and carrier even at the stage of impregnation and burning of the catalyst. As a result the valent state of the part of $\mathrm{Mn}^{2+}$-ions varies and the palladium complexes with $\gamma-\mathrm{Al}_{2} \mathrm{O}_{3}$ are formed. Moreover, the interaction of active components between them is observed causing the shift of the equilibrium $\mathrm{Mn}^{3+}+\mathrm{e}^{-} \leftrightarrow \mathrm{Mn}^{2+}$ on the surface to the formation of $\mathrm{Mn}^{2+}$-ions and to increase of palladium dispersity. 

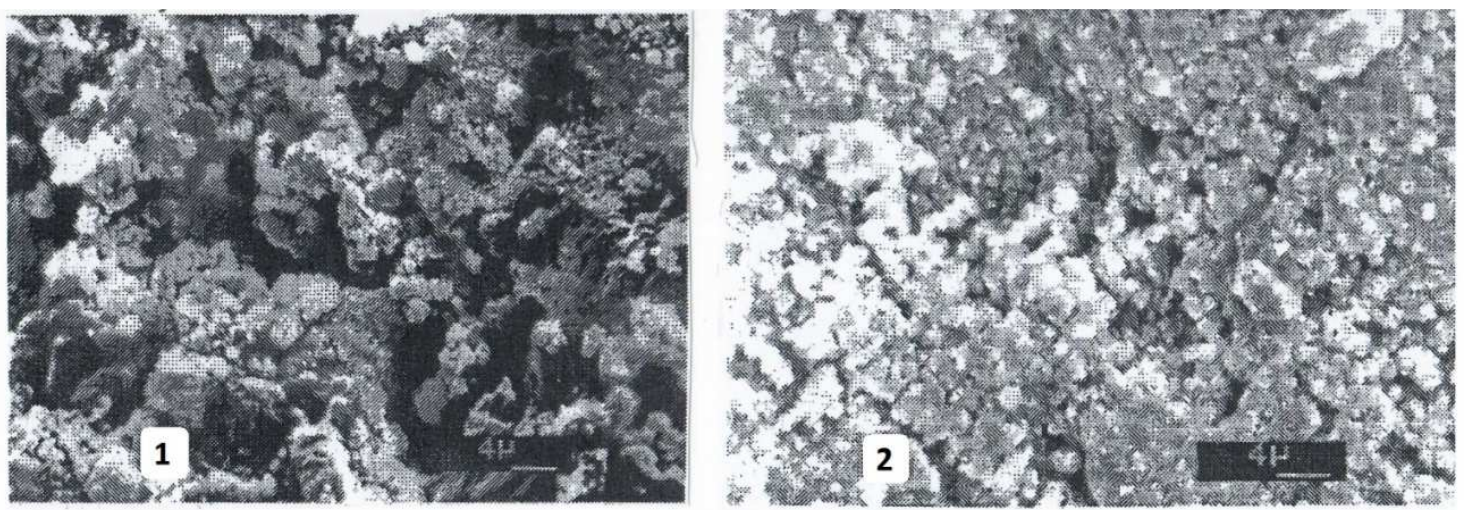

Figure 1. Electron microphotographs of the surface of manganese-palladium (MPK) catalysts at various content of Pd, mass\%; $1-M P K / 0.023$ Pd; 2$M P K / 0.06 P d$.

Pilot bathes of catalyst MPK-1 were tested in combined system of purification of spent gases of diesel locomotive TGM6A [21]. The degree of CO-transformation on initial sample MPK-1 comprises $96-98 \%$ at all specified regimes of locomotive operation. Average content od sulphur in the catalyst after operation over 2000 hours comprises 3-5 mass \%. X-ray spectral microanalysis, performed at electron probe MS-46 (French firm "Cameca"), has shown that sulfur in sulphurized samples of catalysts MPK-1, is distributed in surface layer in the zone of distribution of manganese oxide in contrast to catalyst, deposited at non-modified alumooxide carrier (Figure 2). At catalyst regeneration by washing by hot water the lesser strongly adsorpted sulphur compounds are removed from surface zone and activity is reduced without variation of its strength and other physical-chemical characteristics.

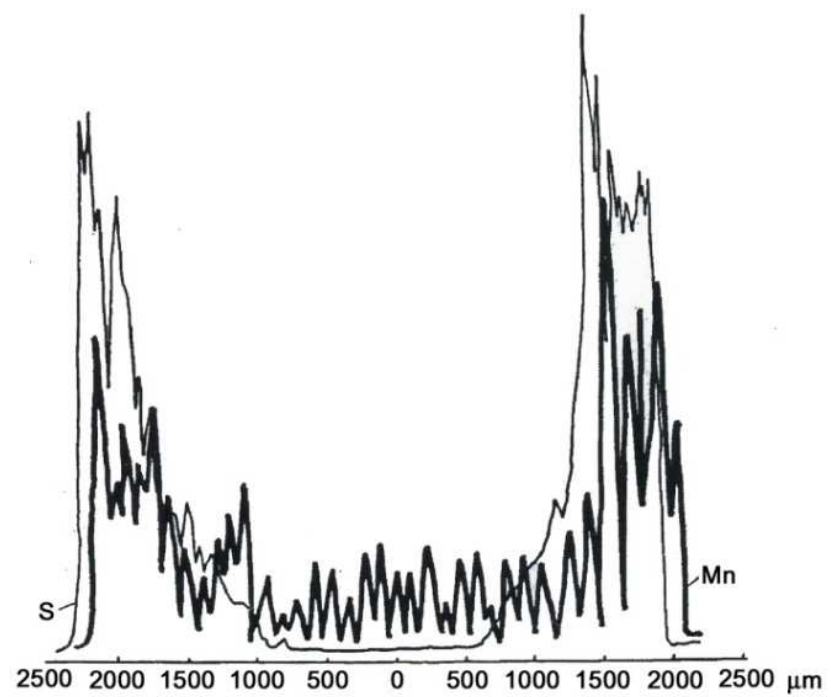

Figure 2. Concentration curves of distribution of Mn and $S$ in sulphurized sample of catalyst MPK-1.

\subsection{Pd-MnOX/Cordierite Catalyst in the CO Oxidation}

For preparation of automobile catalysts, the aluminosilicate blocks with cellular structure are intensively developed. Their specific surfaces, as a rule, don't exceed 0.5 $\mathrm{m}^{2} \mathrm{~g}^{-1}$. The main technical difficulty in the production of block catalysts is the improvement of the technology for the deposition of secondary carrier. It is believed that the development of heat-resistant materials, that can be directly impregnated with catalyst components, can solve this problem [22].

Manganese-palladium catalyst applied on the surface of alumosilicate-cordierite $\left[(\mathrm{Mg}, \mathrm{Fe})_{2} \mathrm{Al}_{4} \mathrm{Si}_{5} \mathrm{O}_{18}\right]$ honeycomb blocks is presented [23]. Manganese oxidesand palladium are applied to the surface of the alumosilicate block by means of a one-time diffusion saturation with solutions of manganese nitrate and palladium chloride. The developed method allows to obtain samples of catalysts containing manganese oxidesand palladium that are uniform in composition and morphology. In this case, palladium covers the surface occupied by manganese oxide, without penetrating into the depth of the pores clogged with $\mathrm{MnO}_{\mathrm{x}}$ particles. The method for preparing of the $\mathrm{Pd}$ and $\mathrm{Mn}-\mathrm{Pd}$ catalysts includes processing the samples with an ammonia of water solution. Before treatment by aqueous ammonia, the $\mathrm{CO}$ oxidation reaction on the catalyst comprised $98-100 \%$ in the temperature range from $205^{\circ} \mathrm{C}$ to $210^{\circ} \mathrm{C}$. After treatment by aqueous ammonia, the same degree of $\mathrm{CO}$-oxidation could be attained even at $175-180^{\circ} \mathrm{C}$. The treatment of the catalyst by ammonia water can lead to the formation of amino-palladium complexes which can decompose with formation of catalytically active palladium black $[24,25]$. Comparison of the decomposition curves of $\mathrm{Pd}-\mathrm{MnO}_{\mathrm{x}} /$ cordierite catalyst with and without treatment by aqueous ammonia, shows the exoeffect on the DTA curve at the temperatures: $255,4^{\circ} \mathrm{C}$ and $350,0^{\circ} \mathrm{C}$ which is indicative of the phase decomposition [23]. This can only be observed in the aqueous ammonia treated sample. Similar promotion effect of aqueousammonia treatment of $\mathrm{Pd} / \mathrm{CA}_{2}$ was observed [26]. From the samples, reduced in the medium ofammonia, hydrogen and formiate, the most active in the reaction of $\mathrm{CO}$-oxidation was the sample treated by solution of $\mathrm{NH}_{4} \mathrm{OH}$.

\section{Main Conclusions}

1) The Physical-chemical and technological prerequisites 
were created and developed for elaboration of the catalysts of new type on the basis of manganese oxides and on their use in the processes of oxidation and hydrogenation.

2) Phisical-chemical and technological foundations of the formation of oxide-manganese catalyst-absorbent are justified theoretically and experimentally. It has been shown that for the processes of purification of combustible gases from $\mathrm{H}_{2} \mathrm{~S}$ and organic sulphur compounds the most favorable thermodynamic and kinetical conditions are created at manganese catalyst the composition of which is near to $\mathrm{Mn}_{3} \mathrm{O}_{4}$.

3) The processes of the formation of oxide-manganese catalysts have been studied at the influence of reaction medium. It can be concluded that the treatment with ammonia water leads to the completion of the formation of the active surface of the catalyst and to the temperature decrease of complete oxidation of $\mathrm{CO}$.

4) The direction, associated with the use of modified alumooxide carrier for elaboration of oxide-manganese and metallic catalyst (Pt, Pd) became as the new and prospective in the technology of carriers and catalysts, used in the processes of oxidation and hydrogenation.

5) In the technology of the catalysts of aluminium oxide, by the use, of the carrier, preliminary modified by calcium oxide, the Mn-Pd catalyst was elaborated available for oxidation of $\mathrm{CO}$ and hydrocarbons of spent gases of the motor transport.

\section{Acknowledgements}

This work was supported by Shota Rustaveli National Science Foundation of Georgia (SRNSFG) (Grant № 18-750).

\section{References}

[1] Chagunava V. Researches on the use of manganese catalysts in chemical industry. Tbilisi, Metsniereba, 1965, p. 139.

[2] Chagunava V. Manganese catalysts for certain reactions. Tbilisi, Metsniereba, 1969, p. 186.

[3] Ioseliani D., Bakhtadze, V., Investigation in the field of heterogenic catalysis, Proc. Georg. Acad. Sci., Chem. Chem. Technol., Metsniereba, Tbilisi, 2001, 120-133.

[4] Bakhtadze, V., Mosidze, V., Janjgava, R., Chochishvili, N., Dzanashvili, D., Kharabadze, N., Pajishvili, M. Preparation of efficient catalysts - adsorbents for cleaning gases from sulfur conpounds, Eur. Chem. Bull,. 2014, 3 (1), 46-49. DOI: http://dx.doi.org/10.17628/ecb.2014.3.46-49.

[5] BakhtadzeV., MdivaniV., ChagunavaV. Activity and physical-chemical characteristics of manganese and manganese-copper catalysts in the course of purification of waste gases. Proceedings of Kazakh Academy of Sciences, Chem. series, 1975, 6, pp. 27-31.

[6] Chagunava V., Mdivani V. Variation of surface potential of manganese catalyst relative to the volume depending on the temperature of reagent medium. Bulletin of the Georgian academy of sciences, Tbilisi, 1969, v. 55, No 2, p. 305-308.
[7] Altshuler V., Gavrilova A.. High- temperature purification of gases from sulphur compounds. M., Nauka, 1969, p. 42.

[8] Bakhtadze V., Mosidze V., Janjgava R., Kartvelishvili D., Oxide-manganese catalysts for the gas purification, $7^{\text {th }}$ International ISTC SAC Seminar. Proceeding of the Conference, Russia, Ekaterinburg, 2005, p. 177-179.

[9] Janjgava R., Bakhtadze V., Mosidze V. Porous structure and phase Composition of Alumocalcium Carriers of catalyst of Methane conversion. Bulletin of the Georgian academy of sciences, Tbilisi, 1999, v. 159, \#1, p. 93-95.

[10] Fionov A., Zaitseva I., Kharlamov A., Lunina E. // Donor-acceptor properties of the surface of aluminum oxide modified by cathionites of sodium and calcium. Kinetika $i$ cataliz, 1997, v. 38, issue 1, p. 155-160.

[11] Rebinder R. Physical-chemical mechanics-new field of Science. Moscow, Znanie, 1958, p. 64.

[12] Bakhtadze V., Kharabadze N., Kartvelishvili D., Mosidze V., Janjgava R. Some regularity of preparing alumocalcium-oxide carriers for gas-washer catalysts. Proceedings of the Georgian Academy of sciences Chemical series, 2004, \# 1-2, T 30, c. 101-105.

[13] Bakhtadze, V., Mosidze, V., Kartvelishvili, D., Janjgava, R., Kharabadze, N., Modification of $\gamma-, \chi-\mathrm{Al}_{2} \mathrm{O}_{3}$ alumina support by calcium oxide for the preparation of oxidation of $\mathrm{CO}$ and hydrcarbons commercial catalysts, Katal. Promysl., 2012, 2, 56- 63.

[14] Bakhtadze V., Sinthesis of catalysts on modified carrier for gas purification, Soviet-french seminar on catalysis, Novosibirsk 90, Iune 18-21. p. 18-20.

[15] Bakhtadze V., Mosidze V., Kartvelishvili D., Kharabadze, N., Janjgava R., Fajishvili M., Chochishvili N. Coated Modified Low-percentage Pd- catalysts of NPK series for CO oxidation. Georgian Chemical Journal, 9 (1) 2009, p. 525 - 528.

[16] Bakhtadze, V., Mosidze, V., Kartvelishvili D., Kharabadze, N., Kikacheishvili M., Janjgava, R., Fajishvili M., Chochishvili N. Deposited Modified Pt - Catalysts of PLK - tipe for CO oxidation. GeorgianChemicalJournal, 10 (3) 2010, p. 316 - 321.

[17] Bakhtadze, V., Kharabadze, N., Moroz, E., Supported Modifed Mn-Pd Catalysts of the MPK-1 Series for CO Oxidation Katal. Promysl., 2007, 3, 115-120.

[18] Ivanova, A., Slavinskaya, E., Stonkus, O., Zaikovskii, V., Danilova, I., Gulyaev, R, Bulavchenko, O, Tsibulya, S., Boronin, A., Low_Temperature Oxidation of Carb Monoxide over $\left(\mathrm{Mn}_{1-\mathrm{x}} \mathrm{M}_{\mathrm{X}}\right) \mathrm{O}_{2}(\mathrm{M}=\mathrm{Co}, \mathrm{Pd})$ Catalysts, Kinetics and Catal., 2013, 54 (1), 81-94. DOI: https://doi.org/10.1134/S0023158413010084

[19] Bakhtadze, V., Mosidze, V., Kharabadze, N., Dzanashvili, D., Janjgava, R., Fajishvili, M., Chochishvili, N., Dyspersity and activity of palladium in $\mathrm{CO}$ oxidation catalists, Khim. $\mathrm{Zh}$, Gruzii, 2014, 14 (1), 100-103.

[20] Savonkina, M., Kupcha, L., Yegizarov, Yu., Potapovich, A., Zhizhenko, G., Zaretsky, M., Physico-chemical study of palladium-manganese catalysts based on aluminium oxide, Vestnik Akad. Navuk BSSR, ser., Chem., 1986, 3, 58-62.

[21] Bakhtadze, V., Mosidze, V., Kharabadze, N., Chochishvili, N., Fajishvili, M., Janjgava, R., Effect of $\mathrm{SO}_{2}$ on the activity and physical-cemical properties of $\mathrm{Mn}-\mathrm{Pd}$ catalyst for $\mathrm{CO}$ oxidation, Slovak Int. Sci. J, 2017, 1 (7), 14-17. DOI: https://doi.org/10.5089/9781475587937.002 
[22] Farrauto, R., Heck, R., Honeycomb catalysts: Present and future Kinet. Katal., 1998, 39 (5), 646- 652.

[23] Bakhtadze V., Mosidze V., Machaladze T., Kharabadze, N., Lochoshvili D., Fajishvili M., Janjgava R., and Mdivani N. Activity of $\mathrm{Pd}-\mathrm{MnOx} /$ cordierite $\left.(\mathrm{Mg}, \mathrm{Fe})_{2} \mathrm{Al}_{4} \mathrm{Si}_{5} \mathrm{O}_{18}\right)$ Catalyst for carbon monoxide oxidation. European Chemical Bulletin, 2020, 9 (2), $75-77 . \quad$ DOI: http//dx.doi.org/10.17628/ecb. 2020. 9. $75-77$.

[24] Platinum metals., A Guide to Preparative Inorganic Chemistry, Edited by G. Brauer., Izdatinlit, 1956, 723-726.
[25] Chernyaev, I., About diamminitrochloropalladium $\left[\mathrm{Pd}\left(\mathrm{NH}_{3}\right)_{2} \mathrm{NO}_{2} \mathrm{Cl}\right]_{2}$, Complex compounds of transition metals, Selected Works, Moscow, Science 1973, 177-184.

[26] Bakhtadze, V., Mosidze, V., Kharabadze, N., Dzanashvili, D., Janjgava, R., Fajishvili, M., Chochishvili, N. Effect of Pd concentraion and reductants on the activity of $\mathrm{C} 0$ oxidation catalysts, khim. Zh. Gruzii, 2015, 15 (1), 66-68. 